\title{
THE LONGITUDINAL STUDY ON THE EFFECTIVENESS OF THE GAME ACTIONS AT THE WORLD WOMAN'S HANDBALL CHAMPIONSHIP SENIORS (2005-2015)
}

\author{
Leuciuc Florin Valentin ${ }^{1 *}$ \\ Pricop Gheorghe 2 \\ 1,2Ștefan cel Mare University of Suceava, 13, Universității, 720229, Romania
}

Keywords: handball, analysis, World Championship, female

\begin{abstract}
This study may lead to the identification of elements that indicate trends of women's handball for the period 2005-2015, thus creating the conditions for determining the principles for achieving training and participation in high level competitions. As a result of comparing the data obtained from the analysis performed should be reconsidered the margins of the monitored actions efficiency as benchmarks to be useful in training and competition, by requiring reconsideration model performance handball game at senior level. Because the research covers six editions of the World Championships and analysed data obtained had a high degree of veridicity and which parts may be used for the following competitions.
\end{abstract}

\section{Introduction}

The first edition of a women's handball World Championship was held in 1949 for outdoor handball and continues with other two editions in 1956 and 1960. Since 1957 organizes World Championships for indoor handball, they will not have rhythmicity in the next 20 years; for the period 1978-1990 is organized every 4 years and since 1993 from 2 to 2 years.

During the time the competition format has undergone some changes in the number of participating teams, the number and structure of the group, number of games played by the participating teams.

Between 1957-1993 the number of participating teams has varied between 8 and 16, there was a group phase, then main groups (since 1993) and placement matches to establishing the final hierarchy.

Since 1995 the number of teams is increased to 20, and from 1997 to 24, which is kept constant the number so far. For the period 1995-2001 the competitional system included a group phase followed by the knockout phase: last 16, quarterfinals, semifinals and final. Between 2003 and 2009 after the

\footnotetext{
*E-mail: florinl@usv.ro tel. 0746/852974
} 
group stage games follow the main groups and then semifinals and finals. Since 2011 after the group stage is the knockout phase - last 16, quarterfinals, semifinals and final.

Regarding the number of games played, it gradually increased with increasing number of participating teams: between 1957 and 1971 was playing 4 to 5 games for each team; between 1973 and 1982 their number was between 3 and 6; during 1986-1993 the number of games was between 4 and 6, and after 1997 their number was between 6 and 9 .

\section{Material and methods}

Determination of the effectiveness of the actions of the participating teams at the World Championships may be a reference to the revaluation model in play at senior level high performance handball.

This study may lead to the identification of elements that indicate trends of female handball for the period 2005-2015, thus creating the conditions for determining the principles for achieving training and participation in high level competitions.

In carrying out the study the main methods used were bibliographical and statistics. Bibliographic method was used by studying of the analyzes conducted after World Championships. Statistical method was used to process the data supplied by IHF for World Championships after competition and game actions quantified we used in the study.

\section{Results and Discussions}

The actions of game that provided the statistical analysis are: efficiency of the throws (6m, wings, 9m, 7m, fast break), goalkeepers efficiency, interception and blocked shots.

For these actions analysis was performed as follows: for all the participating teams (24), places $1-4$, places 5-12, places $1-12$, places $13-24$ (Tab.1-5).

Table 1 Game actions efficiency for all teams (places 1-24)

\begin{tabular}{|c|c|c|c|c|c|c|c|c|c|c|}
\hline \multirow[t]{2}{*}{ Edition } & \multirow{2}{*}{$\begin{array}{c}\text { Statistical } \\
\text { parameters }\end{array}$} & \multicolumn{3}{|c|}{ Shots efficiency (\%) } & \multirow{2}{*}{$\begin{array}{c}\text { 7m shots } \\
(\%)\end{array}$} & \multirow{2}{*}{$\begin{array}{c}\text { Fast break } \\
(\%)\end{array}$} & \multirow{2}{*}{$\begin{array}{c}\text { All shots } \\
\text { (\%) }\end{array}$} & \multirow{2}{*}{$\begin{array}{c}\text { Goalkeepers } \\
\text { (\%) }\end{array}$} & \multirow{2}{*}{$\begin{array}{c}\text { nterception } \\
\text { s } \\
\text { (no.) }\end{array}$} & \multirow{2}{*}{$\begin{array}{l}\text { Blocked } \\
\text { hots (no. }\end{array}$} \\
\hline & & $6 m$ & wing & $9 \mathrm{~m}$ & & & & & & \\
\hline 2005 & $\mathrm{X}$ & 65,17 & 51,42 & 35,04 & 69,88 & 75,71 & 53,67 & 31,21 & 42,33 & 23,67 \\
\hline 2007 & X & 59,00 & 50,46 & 35,92 & 72,21 & 70,92 & 52,21 & 32,42 & 44,50 & 23,75 \\
\hline 2009 & $\mathrm{X}$ & 57,13 & 49,63 & 32,67 & 72,79 & 68,50 & 52,42 & 32,96 & 54,75 & 31,50 \\
\hline 2011 & $\mathrm{X}$ & 55,71 & 49,88 & 33,29 & 78,21 & 75,29 & 53,38 & 31,75 & 34,46 & 23,75 \\
\hline 2013 & $\mathrm{X}$ & 59,79 & 49,29 & 36,63 & 70,96 & 72,75 & 52,88 & 32,38 & 32,04 & 20,46 \\
\hline 2015 & $\mathrm{X}$ & 61,25 & 52,00 & 35,35 & 71,17 & 78,46 & 59,36 & 30,71 & 28,17 & 16,17 \\
\hline & $\mathrm{X} \pm \mathrm{S}$ & \begin{tabular}{|c|}
$59,68 \pm$ \\
3,33 \\
\end{tabular} & $\begin{array}{c}50,45 \pm \\
1,07 \\
\end{array}$ & $\begin{array}{c}34,82 \pm \\
1,53 \\
\end{array}$ & $\begin{array}{c}72,54 \pm \\
, 96 \\
\end{array}$ & $\begin{array}{c}73,61 \pm \\
3,60 \\
\end{array}$ & $\begin{array}{c}53,99 \pm \\
2,69 \\
\end{array}$ & $\begin{array}{c}31,91 \pm \\
0,84 \\
\end{array}$ & $\begin{array}{c}39,38 \pm \\
0,75 \\
\end{array}$ & \begin{tabular}{|c|}
$23,22 \pm$ \\
5,03 \\
\end{tabular} \\
\hline
\end{tabular}


Table 2 Game actions efficiency for places 1-4

\begin{tabular}{|c|c|c|c|c|c|c|c|c|c|c|}
\hline \multirow[t]{2}{*}{ Edition } & \multirow{2}{*}{$\begin{array}{c}\text { Statistical } \\
\text { parameters }\end{array}$} & \multicolumn{3}{|c|}{ Shots efficiency (\%) } & \multirow{2}{*}{$\begin{array}{c}7 \mathrm{~m} \text { shots } \\
(\%)\end{array}$} & \multirow{2}{*}{$\begin{array}{c}\text { Fast break } \\
(\%)\end{array}$} & \multirow{2}{*}{$\begin{array}{l}\text { All shots } \\
(\%)\end{array}$} & \multirow{2}{*}{$\begin{array}{c}\text { Goalkeepers } \\
\text { (\%) }\end{array}$} & \multirow{2}{*}{$\begin{array}{c}\text { Intercep } \\
\text { tions } \\
\text { (no.) }\end{array}$} & \multirow{2}{*}{$\begin{array}{l}\text { Blocked } \\
\text { hots (no.) }\end{array}$} \\
\hline & & $6 \mathrm{~m}$ & wing & $9 \mathrm{~m}$ & & & & & & \\
\hline 2005 & $\mathrm{X}$ & 68,75 & 49,50 & 41,75 & 76,50 & 75,50 & 57,25 & 38,00 & 55,25 & 49,00 \\
\hline 2007 & $\mathrm{X}$ & 63,50 & 54,25 & 42,00 & 76,25 & 73,25 & 59,75 & 38,25 & 63,50 & 44,50 \\
\hline 2009 & $\mathrm{X}$ & 61,50 & 54,50 & 34,50 & 69,00 & 70,50 & 57,00 & 39,75 & 68,50 & 43,75 \\
\hline 2011 & $\mathrm{X}$ & 58,00 & 53,25 & 37,25 & 84,00 & 82,00 & 58,75 & 40,00 & 47,00 & 53,00 \\
\hline 2013 & $\mathrm{X}$ & 66,75 & 53,75 & 41,00 & 75,75 & 77,00 & 58,25 & 37,50 & 42,25 & 37,50 \\
\hline 2015 & $\mathrm{X}$ & 70,50 & 56,00 & 37,00 & 69,75 & 84,50 & 60,75 & 35,75 & 29,25 & 27,00 \\
\hline & $\mathrm{X} \pm \mathrm{S}$ & $\begin{array}{c}64,83 \pm \\
4,71 \\
\end{array}$ & $\begin{array}{c}53,54 \pm \\
2,19 \\
\end{array}$ & $\begin{array}{c}38,92 \pm \\
3,09 \\
\end{array}$ & $\begin{array}{c}75,21 \pm \\
5,45 \\
\end{array}$ & $\begin{array}{c}77,13 \pm \\
5,29 \\
\end{array}$ & $\begin{array}{c}58,63 \pm \\
1,45 \\
\end{array}$ & $\begin{array}{c}38,21 \pm \\
1,56 \\
\end{array}$ & $\begin{array}{c}50,96 \pm \\
14,46 \\
\end{array}$ & $\begin{array}{c}42,46 \pm \\
9,20 \\
\end{array}$ \\
\hline
\end{tabular}

Table 3 Game actions efficiency for places 5-12

\begin{tabular}{|c|c|c|c|c|c|c|c|c|c|c|}
\hline \multirow[t]{2}{*}{ Edition } & \multirow{2}{*}{\begin{tabular}{|c|} 
Statistical \\
parameters
\end{tabular}} & \multicolumn{3}{|c|}{ Shots efficiency (\%) } & \multirow{2}{*}{$\begin{array}{c}7 \mathrm{~m} \text { shots } \\
(\%)\end{array}$} & \multirow{2}{*}{$\begin{array}{c}\text { Fast break } \\
\text { (\%) }\end{array}$} & \multirow{2}{*}{$\begin{array}{l}\text { All shots } \\
\text { (\%) }\end{array}$} & \multirow{2}{*}{$\begin{array}{c}\text { Goalkeepers } \\
\text { (\%) }\end{array}$} & \multirow{2}{*}{$\begin{array}{c}\text { Intercep } \\
\text { tions } \\
\text { (no.) }\end{array}$} & \multirow{2}{*}{$\begin{array}{l}\text { Blocked } \\
\text { hots (no. }\end{array}$} \\
\hline & & $6 \mathrm{~m}$ & wing & $9 \mathrm{~m}$ & & & & & & \\
\hline 2005 & $\mathrm{X}$ & 69,88 & 55,38 & 38,8 & 76,75 & 74 & 56 & & 52,13 & 30,2 \\
\hline 2007 & $\mathrm{X}$ & 60,00 & 50,25 & 38,75 & 74,75 & 71,88 & 55,38 & 32 & 61,50 & 25,00 \\
\hline 2009 & $\mathrm{X}$ & 59,88 & 54,00 & 38,38 & 75,50 & 71,38 & 57,13 & 35,50 & 51,13 & 31,88 \\
\hline 2011 & $\mathrm{X}$ & 60,25 & 57,38 & 36,00 & 80,50 & 81,38 & 57,50 & 33,38 & 35,63 & 24,13 \\
\hline 2013 & $\mathrm{X}$ & 61,50 & 56,38 & 40,25 & 74,13 & 76,13 & 58,25 & 36,25 & 28,38 & 20,50 \\
\hline 2015 & $\mathrm{X}$ & 64,50 & 57,25 & 42,00 & 77,88 & 79,50 & 64,13 & 34,50 & 27,75 & 20,50 \\
\hline & $\mathrm{X} \pm \mathrm{S}$ & $\begin{array}{c}62,67 \pm \\
3,94 \\
\end{array}$ & $\begin{array}{c}55,11 \pm \\
2,69 \\
\end{array}$ & $\begin{array}{c}39,04 \pm \\
2,00 \\
\end{array}$ & $\begin{array}{c}76,59 \pm \\
2,35 \\
\end{array}$ & $\begin{array}{c}75,71 \pm \\
4,08 \\
\end{array}$ & $\begin{array}{c}58,19 \pm \\
3,06 \\
\end{array}$ & $\begin{array}{c}34,29 \pm \\
1,36 \\
\end{array}$ & $\begin{array}{c}42,75 \pm \\
14,09 \\
\end{array}$ & $\begin{array}{c}25,38 \pm \\
4,80 \\
\end{array}$ \\
\hline
\end{tabular}

Table 4 Game actions efficiency for places 1-12

\begin{tabular}{|c|c|c|c|c|c|c|c|c|c|c|}
\hline \multirow[t]{2}{*}{ Edition } & \multirow{2}{*}{$\begin{array}{c}\text { Statistical } \\
\text { parameters }\end{array}$} & \multicolumn{3}{|c|}{ Shots efficiency (\%) } & \multirow{2}{*}{$\begin{array}{c}7 \mathrm{~m} \text { shots } \\
(\%)\end{array}$} & \multirow{2}{*}{$\begin{array}{c}\text { Fast break } \\
(\%)\end{array}$} & \multirow{2}{*}{$\begin{array}{c}\text { All shots } \\
\text { (\%) }\end{array}$} & \multirow{2}{*}{$\begin{array}{c}\text { Goalkeepers } \\
\text { (\%) }\end{array}$} & \multirow{2}{*}{$\begin{array}{c}\text { Intercep } \\
\text { tions } \\
\text { (no.) }\end{array}$} & \multirow{2}{*}{$\begin{array}{l}\text { Blocked } \\
\text { hots (no. }\end{array}$} \\
\hline & & $6 m$ & wing & $9 \mathrm{~m}$ & & & & & & \\
\hline 2005 & $\mathrm{X}$ & 69,50 & 53,42 & 39,83 & 76,67 & 74,50 & 56,92 & 34,83 & 53,17 & 36,50 \\
\hline 2007 & $\mathrm{X}$ & 61,17 & 51,58 & 39,83 & 75,25 & 72,33 & 56,83 & 34,67 & 62,17 & 31,50 \\
\hline 2009 & $\mathrm{X}$ & 60,42 & 54,17 & 37,08 & 73,33 & 71,08 & 57,08 & & 56,92 & 35,83 \\
\hline 2011 & $\mathrm{X}$ & 59,50 & 56,00 & 36,42 & 81,67 & 81,58 & 57,92 & 35,58 & 39,42 & 33,75 \\
\hline 2013 & $\mathrm{X}$ & 63,25 & 55,50 & 40,50 & 74,67 & 76,42 & 58,25 & 36,67 & 33,00 & 26,17 \\
\hline 2015 & $\mathrm{X}$ & 66,50 & 56,83 & 40,33 & 75,17 & 81,17 & 63,00 & 34,92 & 28,25 & 22,67 \\
\hline & $\mathrm{X} \pm \mathrm{S}$ & $\begin{array}{c}63,39 \pm \\
3,90\end{array}$ & $\begin{array}{c}54,58 \pm \\
1,92\end{array}$ & $\begin{array}{c}39,00 \pm \\
1,77\end{array}$ & $\begin{array}{c}76,13 \pm \\
2,92\end{array}$ & $\begin{array}{c}76,18 \pm \\
4,42\end{array}$ & $\begin{array}{c}58,33 \pm \\
2,36\end{array}$ & $\begin{array}{c}35,60 \pm \\
0,98\end{array}$ & $\begin{array}{c}45,49 \pm \\
13,84\end{array}$ & $\begin{array}{c}31,07 \pm \\
5,55\end{array}$ \\
\hline
\end{tabular}

Table 5 Game actions efficiency for places 13-24

\begin{tabular}{|c|c|c|c|c|c|c|c|c|c|c|}
\hline \multirow[t]{2}{*}{ Edition } & \multirow{2}{*}{$\begin{array}{c}\text { Statistical } \\
\text { parameters }\end{array}$} & \multicolumn{3}{|c|}{ Shots efficiency (\%) } & \multirow{2}{*}{$\begin{array}{c}7 \mathrm{~m} \text { shots } \\
(\%)\end{array}$} & \multirow{2}{*}{$\begin{array}{c}\text { Fast break } \\
(\%)\end{array}$} & \multirow{2}{*}{$\begin{array}{c}\text { All shots } \\
\text { (\%) }\end{array}$} & \multirow{2}{*}{$\begin{array}{c}\text { Goalkeepers } \\
\text { (\%) }\end{array}$} & \multirow{2}{*}{$\begin{array}{c}\text { Intercep } \\
\text { tions } \\
\text { (no.) }\end{array}$} & \multirow{2}{*}{$\begin{array}{l}\text { Blocked } \\
\text { hots (no. }\end{array}$} \\
\hline & & $6 \mathrm{~m}$ & wing & $9 \mathrm{~m}$ & & & & & & \\
\hline 2005 & $\mathrm{X}$ & 60,83 & 49,42 & 30,25 & 63,08 & 76,92 & 50,42 & 27,58 & 31,50 & 10,83 \\
\hline 2007 & $\mathrm{X}$ & 56,83 & 49,33 & 32,00 & 69,17 & 69,50 & 47,58 & 30,17 & 26,83 & 16,00 \\
\hline 2009 & $\mathrm{X}$ & 53,83 & 45,08 & 28,25 & 72,25 & 65,92 & 47,75 & 29,00 & 52,58 & 27,17 \\
\hline 2011 & $\mathrm{X}$ & 51,92 & 43,75 & 30,17 & 74,75 & 69,00 & 48,83 & 27,92 & 29,50 & 13,75 \\
\hline 2013 & $\mathrm{X}$ & 56,33 & 43,08 & 32,75 & 67,25 & 69,08 & 47,50 & 28,08 & 31,08 & 14,75 \\
\hline 2015 & $\mathrm{X}$ & 56,00 & 47,17 & 29,91 & 67,17 & 75,75 & 55,00 & 26,50 & 28,08 & 9,67 \\
\hline & $\mathrm{X} \pm \mathrm{S}$ & $\begin{array}{c}55,96 \pm \\
3,02\end{array}$ & $\begin{array}{c}46,31 \pm \\
2,76\end{array}$ & $\begin{array}{c}30,56 \pm \\
1,60\end{array}$ & $\begin{array}{c}68,95 \pm \\
4,13\end{array}$ & $\begin{array}{c}71,03 \pm \\
4,32\end{array}$ & $\begin{array}{c}49,51 \pm \\
2,91\end{array}$ & $\begin{array}{c}28,21 \pm \\
1,26\end{array}$ & $\begin{array}{c}33,26 \pm \\
9,63\end{array}$ & $\begin{array}{c}15,36 \pm \\
6,26\end{array}$ \\
\hline
\end{tabular}


The statistical analysis was performed on several levels: for all the participating teams (24), places 1-4, places 5-12, places 1-12, places 13-24 (tables 1-5); the number of games played by each team is variable: the first 8 ranked disputed 9 or 10 games, 9 to 16 places had between 6 and 9 games, the teams ranked 17 to 24 were each between 5 and 9 games.

At the 6 edition analysed the average efficiency of throws from central $6 \mathrm{~m}$ line was 59.68\% (minimum-55.71\%, maximum-65.17\%) for all participating teams; best efficiency was obtained by the top 4 ranked - $64.83 \%$, then the teams finishing 1 to 12 places - 63.39\%, an average efficiency of $62.67 \%$ had teams finishing 5 to 12 places and the lowest efficiency was obtained teams finishing 13-24 - 55.96\% (Fig. 1).

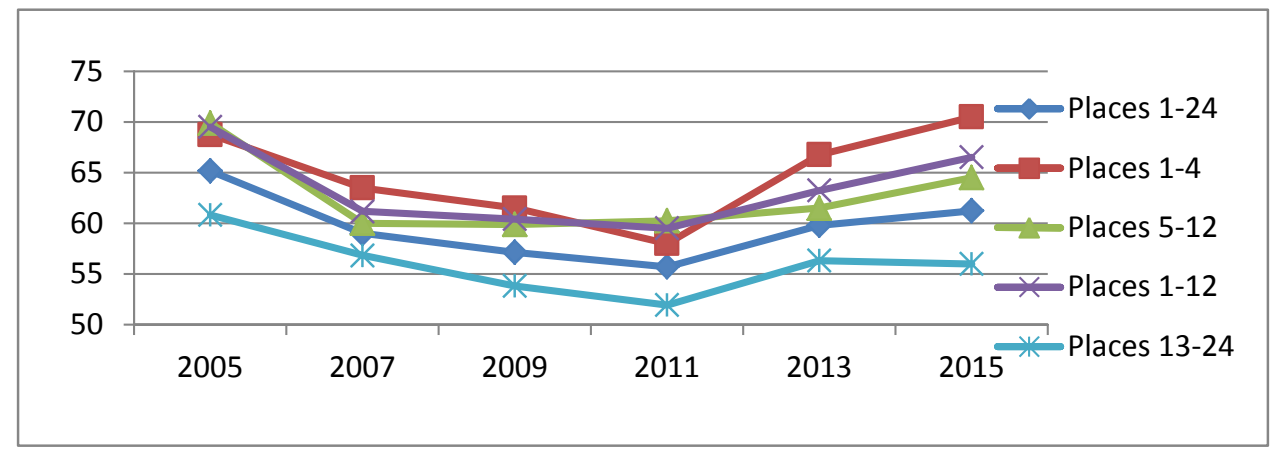

Figure 1. 6m shots efficiency for 2005-2015 period

At the wings shots the best average efficiency have had teams ranked 5-12 places - 55.11\%, followed by teams finishing $1-12-54.58 \%$, then the top 4 teams $-53.54 \%$. The average of all teams was $50.45 \%$ and $46.31 \%$ for last 12 ranked (Fig. 2).

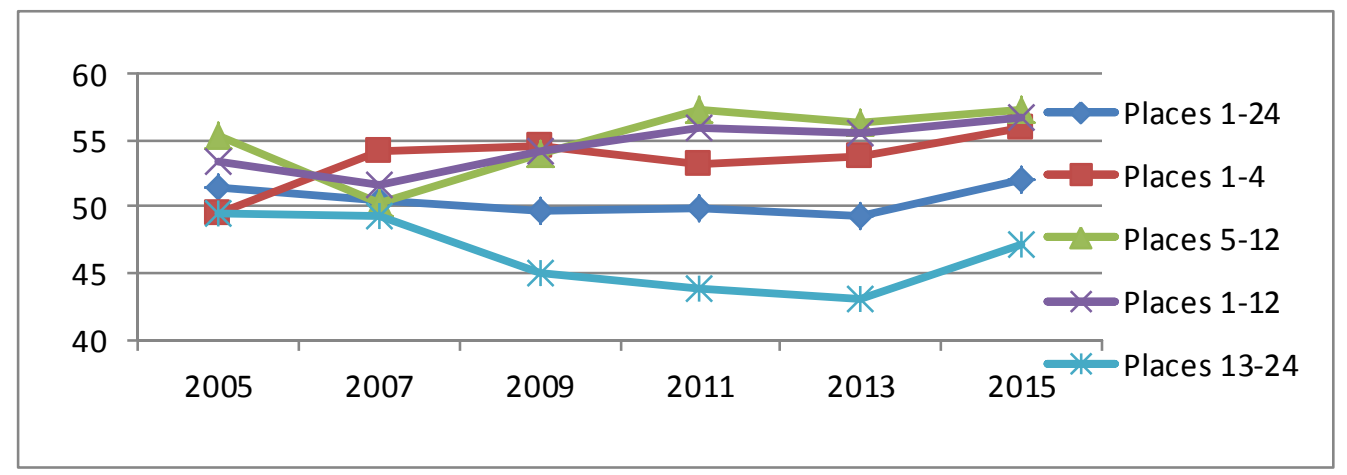

Figure 2. Wings shots efficiency for 2005-2015 period

For $9 \mathrm{~m}$ shots most efficient have had teams in the first half of the hyerarchy (5-12 - 39.04\%, 1 to 12 - 39\% 1-4 - 38.92\%) and the last 12 ranked teams had an average of 30.56\%; all teams average was 34.82\% (Fig. 3). 


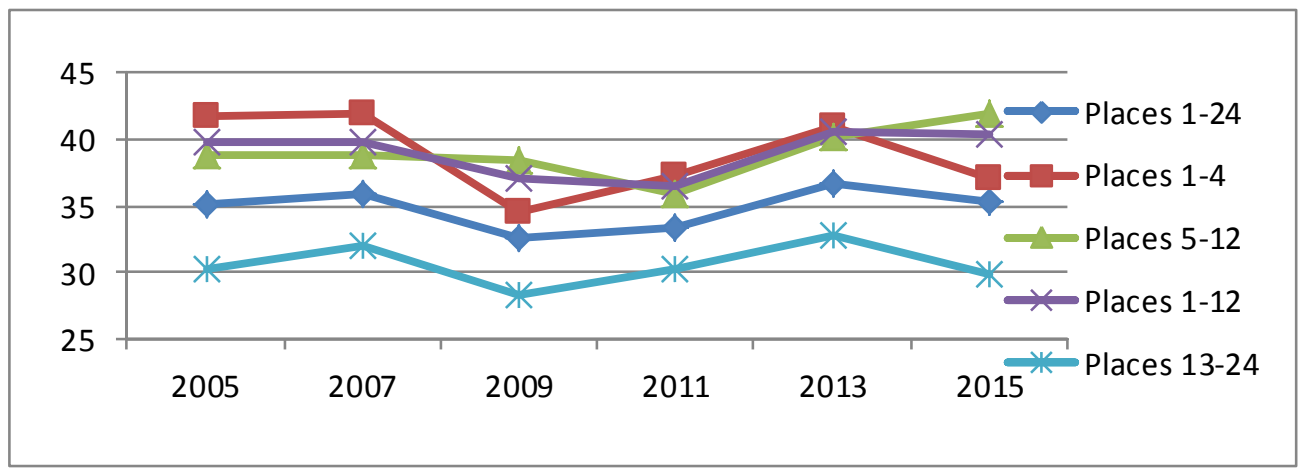

Figure 3. Backcourt shots efficiency for 2005-2015 period

The first 12 ranked teams had at $7 \mathrm{~m}$ shots an average efficiency in the range $75-77 \%$, and for the last 12 ranked teams average was $68.95 \%$. The average of all teams was $72.54 \%$ (Fig. 4).

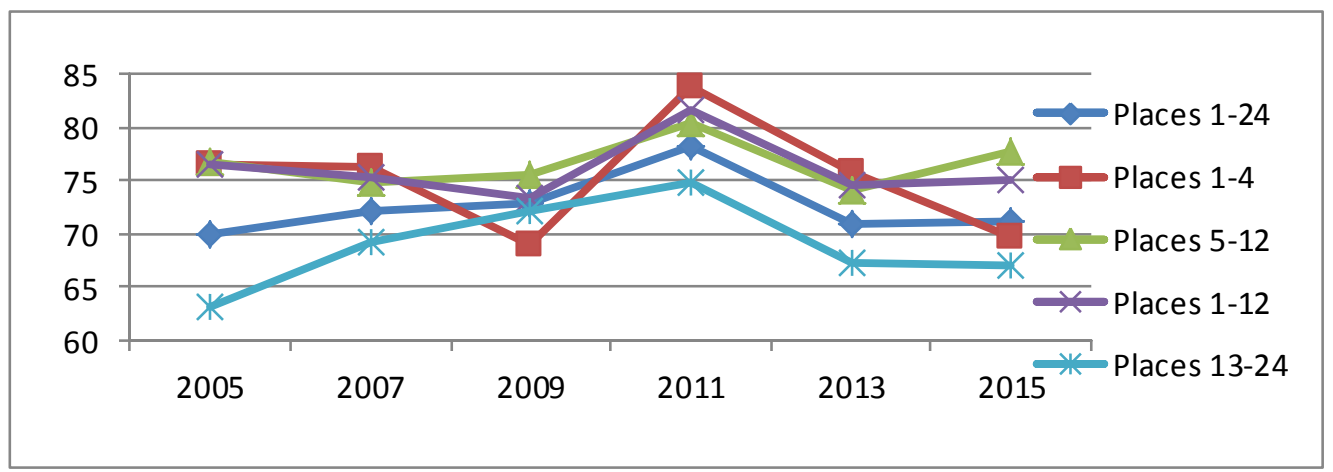

Figure 4. $7 \mathrm{~m}$ shots efficiency for 2005-2015 period

The fast break efficiency was within $75-77 \%$ for first 12 ranked teams, compared to just $71.03 \%$ for the last 12 teams; the average for all teams was 73.61\% (Fig. 5).

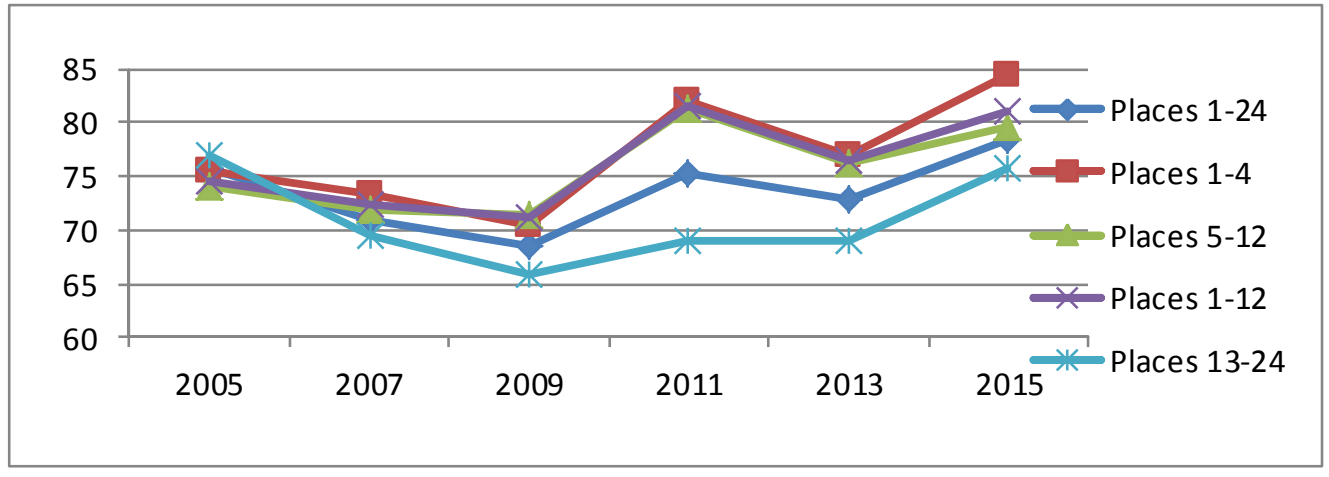

Figure 5. Fast break shots efficiency for 2005-2015 period 
For all the participating teams the shots efficiency average was 53,99\% (minimum-51,21\%, maximum-59,36\%), while the first 4 ranked average was 58,63\% (minimum-57\%, maximum-60,75\%). Teams finishing 5-12 for average was 58,19\% (minimum-55,38\%, maximum-64,13\%); situation for places 1-12 shows an average of 58,33\% (minimum-57,08\%, maximum-63\%) and for places $13-24$ average was 49,51\% (minimum-47,50\%, maximum-55\%) (Fig. 6).

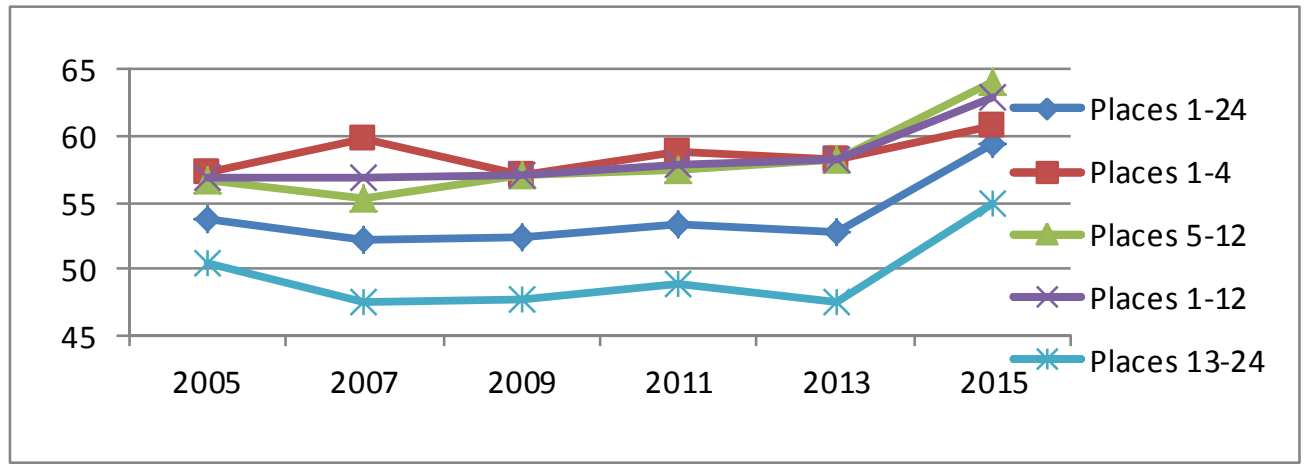

Figure 6. Shots efficiency for 2005-2015 period

The goalkeepers efficiency is crucial in the economy of the game, and their average efficiency of defending throws was 31,91\% (minimum-30,71\%, maximum-32,96\%). On average the efficiency goalkeepers for places 1-4 was $38,21 \%$ (minimum-35,75\%, maximum-40\%); for next 8 teams the average was $34,29 \%$ (minimum-32,88\%, maximum-36,25\%), and for the places 1-12 the average was 35,6\% (minimum-34,67\%, maximum-36,67\%). For the last 12 the average efficiency is 28,21\%. The evolution of efficiency for the 6 final tournaments analysed by category, is shown in figure 7, a downward trend is visible goalkeepers efficiency.

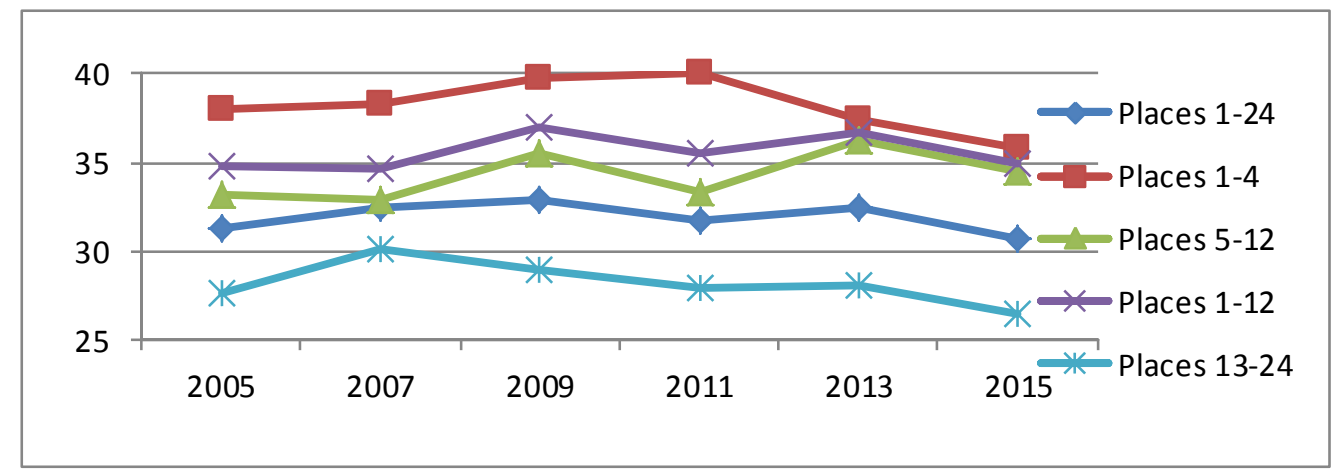

Figure 7. Goalkeepers efficiency for 2005-2015 period

The number of interceptions indicates the offensive tendency of the team and lead the opportunity to score goals easily on fast break. The overall average for all teams participanting is 39,38 interception per team or 5 interception per 
game. For the first 4 ranked average is 50,96 interception per team or 5,65 interception per game; for places 1-12 average is 45,49 per team or 5,6 interception per game; for places 5-12 average is 42,75 per team or 5,3 interception per game; and the last 12 teams the average is 33,26 per team or 4,7 interception per game. The decreasing trend according to the place in the final standings is visible in Fig. 8.

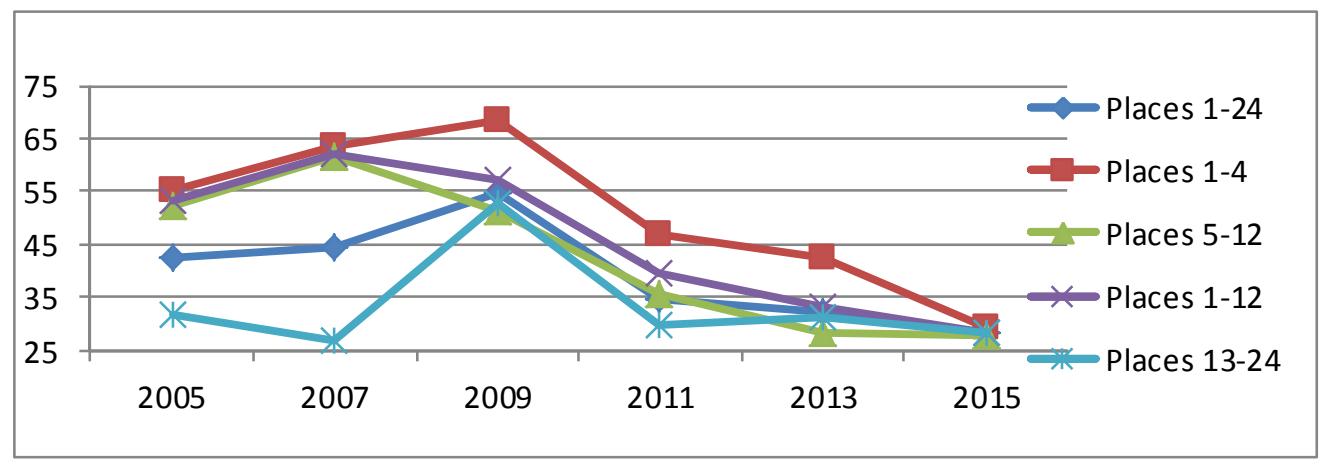

Figure 8. Interceptions number for 2005-2015 period

Another action that could lead to a rebound and increased efficiency of the defence is blocking throws, and the average is 23,22 blocked throws per team or 2,9 blocked throws per game. For 1-4 places average is 42,46 per team and 4,7 per game; for places 5-12 the team average is 25,38 and 3,17 per game; the top 12 ranked teams average is 31,07 per team and 3,45 per game, and last 12 ranked teams average is 15,36 per team and 2,2 per game (Fig. 9).

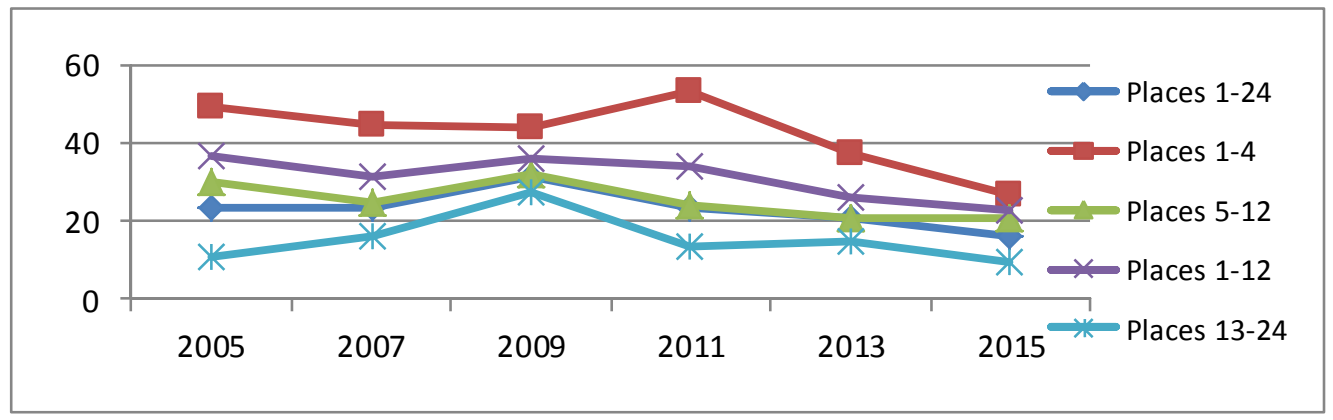

Figure 9. Blocked throws for 2005-2015 period

This study took as benchmark the data of special literature, data regarding the minimum actions efficiency (Taborsky, 2001) and comparing with what we finded (Tab.6).

The attack efficiency is below for the recommended level $(53,99 \%$ $58,63 \%$ vs. $60 \%$ ); the same situation is for $9 \mathrm{~m}$ and wing shots; for $6 \mathrm{~m}$ shots, $7 \mathrm{~m}$ shots and fast break are in the recommended parameters. Regarding to the 
goalkeeper's efficiency it is within parameters for the top 12 ranked teams and below that for all 24 teams.

Table 6 Actions efficiency of our study comparing to the data of special literature

\begin{tabular}{|c|c|c|c|c|}
\hline $\begin{array}{l}\text { Actions } \\
\text { efficiency }\end{array}$ & $\begin{array}{c}\text { Efficiency } \\
\text { (Taborsky } \\
\text { F., 2001) }\end{array}$ & $\begin{array}{c}\text { Efficiency for } \\
\text { all participant } \\
\text { teams (our } \\
\text { study) }\end{array}$ & $\begin{array}{c}\text { Efficiency for } \\
\text { places 1-4 } \\
\text { (our study) }\end{array}$ & $\begin{array}{c}\text { Efficiency for } \\
\text { places 1-12 } \\
\text { (our study) }\end{array}$ \\
\hline all shots & $60 \%$ & $53,99 \%$ & $58,63 \%$ & $58,33 \%$ \\
\hline backcourt shots & $40-45 \%$ & $34,82 \%$ & $38,92 \%$ & $39 \%$ \\
\hline wing shots & $55-60 \%$ & $50,45 \%$ & $53,54 \%$ & $54,58 \%$ \\
\hline $6 \mathrm{~m}$ shots & $60-65 \%$ & $59,68 \%$ & $64,83 \%$ & $63,39 \%$ \\
\hline fastbreak shots & $70-75 \%$ & $71,61 \%$ & $77,13 \%$ & $76,18 \%$ \\
\hline $7 \mathrm{~m}$ shots & $75-80 \%$ & $72,54 \%$ & $75,21 \%$ & $76,13 \%$ \\
\hline $\begin{array}{l}\text { attacks without } \\
\text { shots }\end{array}$ & $15-20 \%$ & $\begin{array}{c}39,38 \text { / } 5 \\
\text { interceptions } \\
23,22 \text { / 2,9 } \\
\text { blocked shots }\end{array}$ & $\begin{array}{c}\text { 59,96 / 5,64 } \\
\text { interceptions } \\
\text { 42,46 / 4,7 } \\
\text { blocked shots }\end{array}$ & $\begin{array}{c}45,49 \text { / 5,6 } \\
\text { interceptions } \\
31,07 \text { / 3,45 } \\
\text { bocked shots }\end{array}$ \\
\hline goalkeepers & $35-40 \%$ & $31,91 \%$ & $38,21 \%$ & $35,60 \%$ \\
\hline
\end{tabular}

\section{Conclusions}

Other studies that treats the same issue indicates that there is a certain lack of consistency during the game and from game to game, which makes in the top 10 ranked teams no significant differences, and mistakes can be decisive for the efficiency and better place in the final standings (Kovacs, 2014, p. 20; p. 26, 2016,).

It is necessary to analyse constantly the evolutions after major competitions to show evolutive trends of the handball game and to set efficiency benchmarks goals in training and competitions (Leuciuc, Pricop, 2015, pp. 4248; 2015b, pp. 27-32; Leuciuc, Pricop, Grosu, Păcuraru, 2015, pp. 58-69).

One of the concerns of the participating teams at the World championships for the period under review was to increase shots efficiency (at all categories) that was characterized by an upward trend although in some editions on average decreases were recorded (Fig. 1 to 6).

The positive trend for shots efficiency influenced negatively the goalkeepers efficiency that has recorded a downward trend because is an inverse relationship between this two indicators (Fig. 7).

The average number of interceptions and blocked shots is important for teams because it favours' increasing of the defence efficiency and scoring goals easy and top ranked teams have made a strategy in this regard, although at the last 4 editions was installed an decreasing trend (Fig. 8 and 9).

As a result of comparing the data obtained from the analysis performed should be reconsidered the actions efficiency margins benchmarks monitored to be useful in training and competition, by requiring the reconsideration of the model of performance in handball game at senior level. Such teams seeking a 
qualification is recommended that efficiency actions to be in places 1-12 margins from Table 4 in the context of the dispute games with teams that consistently qualify for the tournament. In qualifying games the efficiency should be much higher because the teams encountered are of a lower value.

The teams that aspire to winning the competition or medals must exceed requirements for places 1-4 (Tab. 2).

Given that the survey covers the 6 editions of the World Championships and analysed data obtained high degree of veridicity and which parts may be used for the following competitions.

\section{References}

1. KOVACS, P. (2014). Women's European Championship 2014, Croatia/Hungary Qualitative analysis, European Handball Federation, p. 20

2. KOVACS, P. (2016). XII Men's EHF European Handball Championship, 2016, Poland Qualitative analysis, European Handball Federation, p. 26

3. LEUCIUC, F., PRICOP, G. (2015a). Longitudinal study on the effectiveness of the game actions at the European men's handball championship seniors (1998-2014), The Annals of "Dunarea de Jos" University of Galati, Fascicle XV, (1), 42-48, Galaţi University Press;

4. LEUCIUC, F., PRICOP, G. (2015b). Longitudinal study on the effectiveness of the game actions at the World Men's Handball Championship seniors (2005-2015), The Annals of "Dunarea de Jos" University of Galati, Fascicle XV, (2), 27-32, Galaţi University Press;

5. LEUCIUC, F.V., PRICOP, G., GROSU, B., PĂCURARU, A. (2015). Longitudinal study on the effectiveness of the game actions at the European woman's handball championship seniors (2006-2014), Sport and Society. Interdisciplinary Journal of Physical Education and Sports, 16 (Special issue), 58-69, Iaşi;

6. TABORSKY, F. (2001). Game performance in handball, European Handball Federation - Handball Periodical, 2, 26, Vienna: AVISWerbung;

7. http://www.ihf.info/enus/ihfcompetitions/competitionsarchive/womenworldchampionships.aspx

8. http://www.ihf.info/upload/matchresuts/russia_2005/index.htm

9. http://www.ihf.info/upload/matchresuts/russia_2005/PDF/topteam1.pdf

10. http://www.ihf.info/enus/ihfcompetitions/worldchampionships/womensworl dchampionships/xviiiwomenshandballworldchampionshipfrance2/statistics. aspx

11. http://www.ihf.info/files/Uploads/Documents/8414_TOPTEAM.pdf

12. http://www.ihf.info/enus/ihfcompetitions/worldchampionships/womensworl dchampionships/xixwomenhandballworldchampionship2009/statistics.aspx

13. http://www.ihf.info/files/Uploads/Documents/8237_TOPTEAM.pdf

14. http://www.ihf.info/files/competitiondata/7cdd60f1-d892-4b69-8234b2f4f06f5ffc/pdf/TOPTeam.pdf 
15. http://www.ihf.info/files/competitiondata/54b062a3-27c5-42cf-b2aacc31db665425/pdf/TOPTeam.pdf

16. http://www.ihf.info/files/competitiondata/1a09fa5c-ab1f-4b5b-b0c05eee5435d1d4/pdf/TOPTeam.pdf

\title{
STUDIU LONGITUDINAL PRIVIND EFICIENTTAA ACȚIUNILOR DE JOC LA CAMPIONATELE MONDIALE DE HANDBAL FEMININ SENIORI (2005-2015)
}

\author{
Leuciuc Florin Valentin ${ }^{1}$ \\ Pricop Gheorghe 2 \\ 1,2Universitatea "Ștefan cel Mare" Suceava Strada Universității, nr. 13, 720229, \\ Romania
}

Cuvinte cheie: handbal, analiza, campionat mondial, feminin

\section{Rezumat}

Realizarea acestui studiu poate conduce la identificarea unor elemente care să indice tendințele de evoluție ale jocului de handbal feminin pentru perioada 2005-2015, creând astfel premisele pentru stabilirea unor principii de realizare a pregătire și participare în competițiile de înalt nivel. Ca urmare a comparării datelor obținute în urma analizei efectuate ar trebui reconsiderate marjele de eficiență ale acțiunilor monitorizate pentru a fi repere utile în pregătire și competiție, impunându-se reconsiderarea modelului de joc în handbalul de performanță la nivel de seniori. Deoarece studiul acoperă 6 ediții ale campionatelor mondiale datele obținute și analizate au grad înalt de veridicitate și pot fi utilizate care repere pentru următoarele competitiii.

\section{Introducere}

Prima ediție a unui Campionat Mondial de handbal feminin a fost organizată în 1949 la handbal în 11, continuate cu alte 2 ediții în anii 1956 și 1960.Începând cu 1957 se organizează campionate mondiale la handbal în 7, ele neavând o ritmicitate în următorii 20 de ani; pentru intervalul 1978-1990 se organizează o dată la 4 ani, iar din 1993 din 2 în 2 ani.

Pe parcursul desfășurării campionatelor mondiale formatul competiției a suferit câteva modificări în privința numărului de echipe participante, numărul și structura grupelor, numărul de jocuri disputate de echipele participante.

În perioada 1957-1993 numărul echipelor participante a variat între 8 și 16, în general existând o faza a grupelor, apoi grupe principale (din 1993) și jocurile de clasament pentru stabilirea ierarhiei finale.

Din 1995 numărul echipelor crește la 20, iar din 1997 la 24, număr care se menține constant până în prezent. Pentru perioada 1995-2001 sistemul de desfăşurare a cuprins o faza a grupelor urmată de faza eliminatorie: optimi, 
sferturi de finală, semifinale, finală. Între anii 2003 și 2009 după faza grupelor urmau jocurile din grupele principale apoi semifinale și finale. Începând cu anul 2011 după faza grupelor se trece la cea eliminatorie - optimi, sferturi de finală, semifinale, finală.

În privința numărului de jocuri disputate, acesta crescut treptat, o dată cu creșterea numărului de echipe participante: între 1957 și 1971 se jucau între 4 și 5 jocuri de echipă, între 1973 și 1982 numărul lor a fost între 3 și 6; în perioada 1986-1993 numărul jocurile a fost între 4 și 6, iar după 1997 numărul lor a fost între 6 și 9.

\section{Material şi metode}

Determinarea eficienței acțiunilor de joc la echipele participante la campionatele mondiale de handbal feminin poate constitui un reper în reevaluarea modelului de joc la nivel de seniori în handbalul de înaltă performanță.

Realizarea acestui studiu poate conduce la identificarea unor elemente care să indice tendințele de evoluție ale jocului de handbal feminin pentru perioada 2005-2015, creând astfel premisele pentru stabilirea unor principii de realizare a pregătire și participare în competițiile de înalt nivel.

În realizarea studiului principalele metode cercetare utilizate au fost bibliografică și statistică. Metodă bibliografică a fost utilizată pentru studiul analizelor efectuate ca urmare a desfãşurării campionatelor mondiale. Metoda statistică a fost folosită pentru a prelucra datele furnizate de I.H.F. după desfășurarea campionatelor mondiale, iar acțiunile de joc cuantificate le-am utilizat în realizarea studiului.

\section{Rezultate și discuții}

Acțiunile de joc pentru care s-a realizat analiza statistică sunt: eficiența aruncărilor $(6 \mathrm{~m}$, extreme, $9 \mathrm{~m}, 7 \mathrm{~m}$, contraatac), eficiența portarilor, intercepții și mingi blocate. Pentru aceste acțiuni analiza a fost realizată astfel: pentru toate echipele participante (24), locurile 1-4, locurile 5-12, locurile 1-12, locurile 1324 (Tab. 1-5).

Tabel 1 Eficiența acțiunilor pentru toate echipele (locurile 1-24)

\begin{tabular}{|c|c|c|c|c|c|c|c|c|c|c|}
\hline \multirow[t]{2}{*}{ Ediția } & \multirow{2}{*}{$\begin{array}{l}\text { Parametrul } \\
\text { statistic }\end{array}$} & \multicolumn{3}{|c|}{ Eficiența aruncărilor (\%) } & \multirow{2}{*}{$\begin{array}{c}\text { Eficiența } \\
\text { aruncărilor } \\
\text { de la } 7 \mathrm{~m}(\%)\end{array}$} & \multirow{2}{*}{$\begin{array}{c}\text { Eficiența } \\
\text { contraataculu } \\
\text { (\%) }\end{array}$} & \multirow{2}{*}{$\begin{array}{l}\text { Eficiența } \\
\text { aruncărilor } \\
\text { (\%) }\end{array}$} & \multirow{2}{*}{$\begin{array}{c}\text { Eficiența } \\
\text { portarilor } \\
\text { (\%) }\end{array}$} & \multirow{2}{*}{$\begin{array}{c}\text { Interceptii } \\
\text { (nr.) }\end{array}$} & \multirow{2}{*}{$\begin{array}{c}\text { Aruncări } \\
\text { blocate } \\
\text { (nr.) }\end{array}$} \\
\hline & & $6 \mathrm{~m}$ & $\begin{array}{l}\text { extre } \\
\text { me }\end{array}$ & $9 \mathrm{~m}$ & & & & & & \\
\hline 2005 & $\bar{X}$ & 65,17 & 51,42 & 35,04 & 69,88 & 75,71 & 53,67 & 31,21 & 42,33 & 23,67 \\
\hline 2007 & $\mathrm{X}$ & 59,00 & 50,46 & 35,92 & 72,21 & 70,92 & 52,21 & 32,42 & 50 & 23,75 \\
\hline 2009 & $\mathrm{X}$ & 57,13 & 49,63 & 32,67 & 72,79 & 68,50 & 52,42 & 32,96 & 54,75 & 31,50 \\
\hline 2011 & $\mathrm{X}$ & 55,71 & 49,88 & 33,29 & 78,21 & 75,29 & 53,38 & 31,75 & 34,46 & 23,75 \\
\hline 2013 & $\bar{X}$ & 59,79 & 49,29 & 36,63 & 70,96 & 72,75 & 52,88 & 32,38 & 32,04 & 20,46 \\
\hline 2015 & $\mathrm{X}$ & 61,25 & 52,00 & 35,35 & 71,17 & 78,46 & 59,36 & 30,71 & 28,17 & 16,17 \\
\hline & $\mathrm{X} \pm \mathrm{S}$ & $\begin{array}{c}59,68 \pm \\
3,33\end{array}$ & $\begin{array}{c}50,45 \pm \\
1,07\end{array}$ & $\begin{array}{c}34,82 \pm \\
1,53\end{array}$ & $\begin{array}{c}72,54 \pm \\
2,96\end{array}$ & $\begin{array}{c}73,61 \pm \\
3,60\end{array}$ & $\begin{array}{c}53,99 \pm \\
2,69\end{array}$ & $\begin{array}{c}31,91 \pm \\
0,84\end{array}$ & $\begin{array}{c}39,38 \pm \\
0,75\end{array}$ & $\begin{array}{c}23,22 \pm \\
5,03\end{array}$ \\
\hline
\end{tabular}


Tabel 2 Eficiența acțiunilor pentru locurile 1-4

\begin{tabular}{|c|c|c|c|c|c|c|c|c|c|c|}
\hline \multirow[t]{2}{*}{ Ediția } & \multirow{2}{*}{$\begin{array}{l}\text { Parametrul } \\
\text { statistic }\end{array}$} & \multicolumn{3}{|c|}{ Eficiența aruncărilor (\%) } & \multirow{2}{*}{$\begin{array}{c}\text { Eficiența } \\
\text { aruncărilor } \\
\text { de la } 7 \mathrm{~m}(\%)\end{array}$} & \multirow{2}{*}{\begin{tabular}{|c|} 
Eficiența \\
fontraatacului \\
$(\%)$
\end{tabular}} & \multirow{2}{*}{\begin{tabular}{|c|} 
Eficiența \\
aruncărilor \\
(\%)
\end{tabular}} & \multirow{2}{*}{$\begin{array}{c}\text { Eficiența } \\
\text { portarilor } \\
(\%)\end{array}$} & \multirow{2}{*}{$\begin{array}{c}\text { Intercepții } \\
\text { (nr.) }\end{array}$} & \multirow{2}{*}{$\begin{array}{c}\text { Aruncări } \\
\text { blocate } \\
\text { (nr.) }\end{array}$} \\
\hline & & $6 m$ & $\begin{array}{l}\text { extre } \\
\text { me }\end{array}$ & $9 \mathrm{~m}$ & & & & & & \\
\hline 2005 & $\mathrm{X}$ & 68,75 & 49,50 & 41,75 & 76,50 & 75,50 & 57,25 & 38,00 & 55,25 & 49,00 \\
\hline 2007 & $\mathrm{X}$ & 63,50 & 54,25 & 42,00 & 76,25 & 73,25 & 59,75 & 38,25 & 63,50 & 44,50 \\
\hline 2009 & $\mathrm{X}$ & 61,50 & 54,50 & 34,50 & 69,00 & 70,50 & 57,00 & 39,75 & 68,50 & 43,75 \\
\hline 2011 & $\mathrm{X}$ & 58,00 & 53,25 & 37,25 & 84,00 & 82,00 & 58,75 & 40,00 & 47,00 & 53,00 \\
\hline 2013 & $\mathrm{X}$ & 66,75 & 53,75 & 41,00 & 75,75 & 77,00 & 58,25 & 37,50 & 42,25 & 37,50 \\
\hline 2015 & $\mathrm{X}$ & 70,50 & 56,00 & 37,00 & 69,75 & 84,50 & 60,75 & 35,75 & 29,25 & 27,00 \\
\hline & $\mathrm{X} \pm \mathrm{S}$ & $\begin{array}{c}64,83 \pm \\
4,71\end{array}$ & $\begin{array}{c}53,54 \pm \\
2,19\end{array}$ & $\begin{array}{c}38,92 \pm \\
3,09\end{array}$ & $\begin{array}{c}75,21 \pm \\
5,45\end{array}$ & $\begin{array}{c}77,13 \pm \\
5,29\end{array}$ & $\begin{array}{c}58,63 \pm \\
1,45\end{array}$ & $\begin{array}{c}38,21 \pm \\
1,56\end{array}$ & $\begin{array}{c}50,96 \pm \\
14,46\end{array}$ & $\begin{array}{c}42,46 \pm \\
9,20\end{array}$ \\
\hline
\end{tabular}

Tabel 3 Eficiența acțiunilor pentru locurile 5-12

\begin{tabular}{|c|c|c|c|c|c|c|c|c|c|c|}
\hline \multirow[t]{2}{*}{ Ediția } & \multirow{2}{*}{$\begin{array}{c}\text { Parametrul } \\
\text { statistic }\end{array}$} & \multicolumn{3}{|c|}{ Eficiența aruncărilor (\%) } & \multirow{2}{*}{$\begin{array}{c}\text { Eficiența } \\
\text { aruncărilor } \\
\text { de la } 7 \mathrm{~m}(\%)\end{array}$} & \multirow{2}{*}{\begin{tabular}{|c|} 
Eficiența \\
contraatacului \\
$(\%)$
\end{tabular}} & \multirow{2}{*}{\begin{tabular}{|c|} 
Eficiența \\
iaruncărilor \\
$(\%)$
\end{tabular}} & \multirow{2}{*}{$\begin{array}{c}\text { Eficiența } \\
\text { portarilor } \\
(\%)\end{array}$} & \multirow{2}{*}{$\begin{array}{c}\text { Interceptii } \\
\text { (nr.) }\end{array}$} & \multirow{2}{*}{$\begin{array}{c}\text { Aruncăr } \\
\text { blocate } \\
\text { (nr.) }\end{array}$} \\
\hline & & $6 \mathrm{~m}$ & $\begin{array}{c}\text { extre } \\
\text { me }\end{array}$ & $9 \mathrm{~m}$ & & & & & & \\
\hline 2005 & $\mathrm{X}$ & 69,88 & 55,38 & 38,88 & 76,75 & 74,00 & 56,75 & 33,25 & 52,13 & 30,25 \\
\hline 2007 & $\mathrm{X}$ & 60,00 & 50,25 & 38,75 & 74,75 & 71,88 & 55,38 & 32,88 & 61,50 & 25,00 \\
\hline 2009 & $\mathrm{X}$ & 59,88 & 54,00 & 38,38 & 75,50 & 71,38 & 57,13 & 35,50 & 13 & 31,88 \\
\hline 2011 & $\mathrm{X}$ & 60,25 & 57,38 & 36,00 & 80,50 & 81,38 & 57,50 & 33,38 & 35,63 & 24,13 \\
\hline 2013 & $\mathrm{X}$ & 61,50 & 56,38 & 40,25 & 74,13 & 76,13 & 58,25 & 36,25 & 28,38 & 20,50 \\
\hline 2015 & $\mathrm{X}$ & 64,50 & 57,25 & 42,00 & 77,88 & 79,50 & 64,13 & 34,50 & 27,75 & 20,50 \\
\hline & $\mathrm{X} \pm \mathrm{S}$ & $\begin{array}{c}62,67 \pm \\
3,94 \\
\end{array}$ & $\begin{array}{c}55,11 \pm \\
2,69 \\
\end{array}$ & $\begin{array}{c}39,04 \pm \\
2,00 \\
\end{array}$ & $\begin{array}{c}76,59 \pm \\
2,35 \\
\end{array}$ & $\begin{array}{c}75,71 \pm \\
4,08 \\
\end{array}$ & $\begin{array}{c}58,19 \pm \\
3,06 \\
\end{array}$ & $\begin{array}{c}34,29 \pm \\
1,36\end{array}$ & $\begin{array}{c}42,75 \pm \\
14,09 \\
\end{array}$ & $\begin{array}{c}25,38 \pm \\
4,80 \\
\end{array}$ \\
\hline
\end{tabular}

Tabel 4 Eficiența acțiunilor pentru locurile 1-12

\begin{tabular}{|c|c|c|c|c|c|c|c|c|c|c|}
\hline \multirow[t]{2}{*}{ Ediți } & \multirow{2}{*}{$\begin{array}{l}\text { Parametrul } \\
\text { statistic }\end{array}$} & \multicolumn{3}{|c|}{ Eficiența aruncărilor (\%) } & \multirow{2}{*}{$\begin{array}{c}\text { Eficiența } \\
\text { aruncărilor } \\
\text { de la } 7 \mathrm{~m}(\%)\end{array}$} & \multirow{2}{*}{\begin{tabular}{|c} 
Eficiența \\
contraataculu \\
$(\%)$
\end{tabular}} & \multirow{2}{*}{\begin{tabular}{|c|}
$\begin{array}{c}\text { Eficiența } \\
\text { aruncărilor } \\
(\%)\end{array}$ \\
\end{tabular}} & \multirow{2}{*}{$\begin{array}{l}\text { Eficiența } \\
\text { portarilor } \\
\text { (\%) }\end{array}$} & \multirow{2}{*}{$\begin{array}{c}\text { Intercepții } \\
\text { (nr.) }\end{array}$} & \multirow{2}{*}{$\begin{array}{c}\text { Aruncări } \\
\text { blocate } \\
\text { (nr.) }\end{array}$} \\
\hline & & $6 m$ & wing & $9 \mathrm{~m}$ & & & & & & \\
\hline 2005 & $\mathrm{X}$ & 69,50 & 53,42 & 39,83 & 76,67 & 74,50 & 56,92 & 34,83 & 53,17 & 36,50 \\
\hline 2007 & $\mathrm{X}$ & 61,17 & 51,58 & 39,83 & 75,25 & 72,33 & 56,83 & 34,67 & 62,17 & 31,50 \\
\hline 2009 & $\mathrm{X}$ & 60,42 & 54,17 & 37,08 & 73,33 & 71,08 & 57,08 & 36,92 & 56,92 & 35,83 \\
\hline 2011 & $\mathrm{X}$ & 59,50 & 56,00 & 36,42 & 81,67 & 81,58 & 57,92 & 35,58 & 39,42 & 33,75 \\
\hline 2013 & $\mathrm{X}$ & 63,25 & 55,50 & 40,50 & 74,67 & 76,42 & 58,25 & 36,67 & 33,00 & 26,17 \\
\hline 2015 & $\mathrm{X}$ & 66,50 & 56,83 & 40,33 & 75,17 & 81,17 & 63,00 & 34,92 & 28,25 & 22,67 \\
\hline & $\mathrm{X} \pm \mathrm{S}$ & $\begin{array}{c}63,39 \pm \\
3,90\end{array}$ & $\begin{array}{c}54,58 \pm \\
1,92\end{array}$ & $\begin{array}{c}39,00 \pm \\
1,77\end{array}$ & $\begin{array}{c}76,13 \pm \\
2,92\end{array}$ & $\begin{array}{c}76,18 \pm \\
4,42\end{array}$ & $\begin{array}{c}58,33 \pm \\
2,36\end{array}$ & $\begin{array}{c}35,60 \pm \\
0,98 \\
\end{array}$ & $\begin{array}{c}45,49 \pm \\
13,84 \\
\end{array}$ & $\begin{array}{c}31,07 \pm \\
5,55 \\
\end{array}$ \\
\hline
\end{tabular}

Tabel 5 Eficiența acțiunilor pentru locurile 13-24

\begin{tabular}{|c|c|c|c|c|c|c|c|c|c|c|}
\hline \multirow{2}{*}{\multicolumn{2}{|c|}{$\begin{array}{c}\text { Ediția Parametrul } \\
\text { statistic }\end{array}$}} & \multicolumn{3}{|c|}{ Eficiența aruncărilor (\%) } & \multirow{2}{*}{$\begin{array}{c}\text { Eficiența } \\
\text { aruncărilor } \\
\text { de la } 7 \mathrm{~m}(\%)\end{array}$} & \multirow{2}{*}{\begin{tabular}{|c|}
$\begin{array}{c}\text { Eficiența } \\
\text { contraatacului } \\
(\%)\end{array}$ \\
\end{tabular}} & \multirow{2}{*}{$\begin{array}{c}\text { Eficiența } \\
\text { aruncărilor } \\
\text { (\%) }\end{array}$} & \multirow{2}{*}{$\begin{array}{c}\text { Eficiența } \\
\text { portarilor } \\
(\%) \\
\end{array}$} & \multirow{2}{*}{$\begin{array}{l}\text { Intercepții } \\
\text { (nr.) }\end{array}$} & \multirow{2}{*}{$\begin{array}{c}\text { Aruncări } \\
\text { blocate } \\
\text { (nr.) }\end{array}$} \\
\hline & & $6 \mathrm{~m}$ & wing & $9 \mathrm{~m}$ & & & & & & \\
\hline 2005 & $\mathrm{X}$ & 60,83 & 49,42 & 30,25 & 63,08 & 76,92 & 50,42 & 27,58 & 31,50 & 10,83 \\
\hline 2007 & $\mathrm{X}$ & 56,83 & 49,33 & 32,00 & 69,17 & 69,50 & 47,58 & 30,17 & 26,83 & 16,00 \\
\hline 2009 & $\mathrm{X}$ & 53,83 & 45,08 & 28,25 & 72,25 & 65,92 & 47,75 & 29,00 & 52,58 & 27,17 \\
\hline 2011 & $\mathrm{X}$ & 51,92 & 43,75 & 30,17 & 74,75 & 69,00 & 48,83 & 27,92 & 29,50 & 13,75 \\
\hline 2013 & $\mathrm{X}$ & 56,33 & 43,08 & 32,75 & 67,25 & 69,08 & 47,50 & 28,08 & 31,08 & 14,75 \\
\hline 2015 & $\mathrm{X}$ & 56,00 & 47,17 & 29,91 & 67,17 & 75,75 & 55,00 & 26,50 & 28,08 & 9,67 \\
\hline & $\mathrm{X} \pm \mathrm{S}$ & $\begin{array}{c}55,96 \pm \\
3,02\end{array}$ & $\begin{array}{c}46,31 \pm \\
2,76\end{array}$ & $\begin{array}{c}30,56 \pm \\
1,60\end{array}$ & $\begin{array}{c}68,95 \pm \\
4,13\end{array}$ & $\begin{array}{c}71,03 \pm \\
4,32\end{array}$ & $\begin{array}{c}49,51 \pm \\
2,91\end{array}$ & $\begin{array}{c}28,21 \pm \\
1,26\end{array}$ & $\begin{array}{c}33,26 \pm \\
9,63\end{array}$ & $\begin{array}{c}15,36 \pm \\
6,26\end{array}$ \\
\hline
\end{tabular}


Analiza statistică a fost realizată pe mai multe paliere: pentru toate echipele participante (24), locurile 1-4, locurile 5-12, locurile 1-12, locurile 1324 (Tab.1-5); numărul jocurilor disputate de fiecare echipă este variabil și depinde de poziția ocupată în clasament: primele 8 clasate au disputat câte 9 sau 10 jocuri, cele clasate pe locurile 9-16 au avut între 6 și 9 jocuri, echipele clasate pe locurile 17-24 au avut între 5 și 9 jocuri.

La cele 6 ediții analizate media eficienței aruncărilor din zona centrală a liniei de $6 \mathrm{~m}$ a fost de 59,68\% (minim-55,71\%, maxim-65,17\%) pentru toate echipele participante; cea mai bună eficiență a fost obținută de primele 4 clasate - 64,83\%, apoi de echipele clasate pe locurile 1-12 - 63,39\%, o eficienţă medie de $62,67 \%$ au avut-o echipele clasate pe locurile 5-12, iar cea mai slabă eficienţă a fost obţinută de echipele clasate pe locurile 13-24 - 55,96\% (Fig. 1).

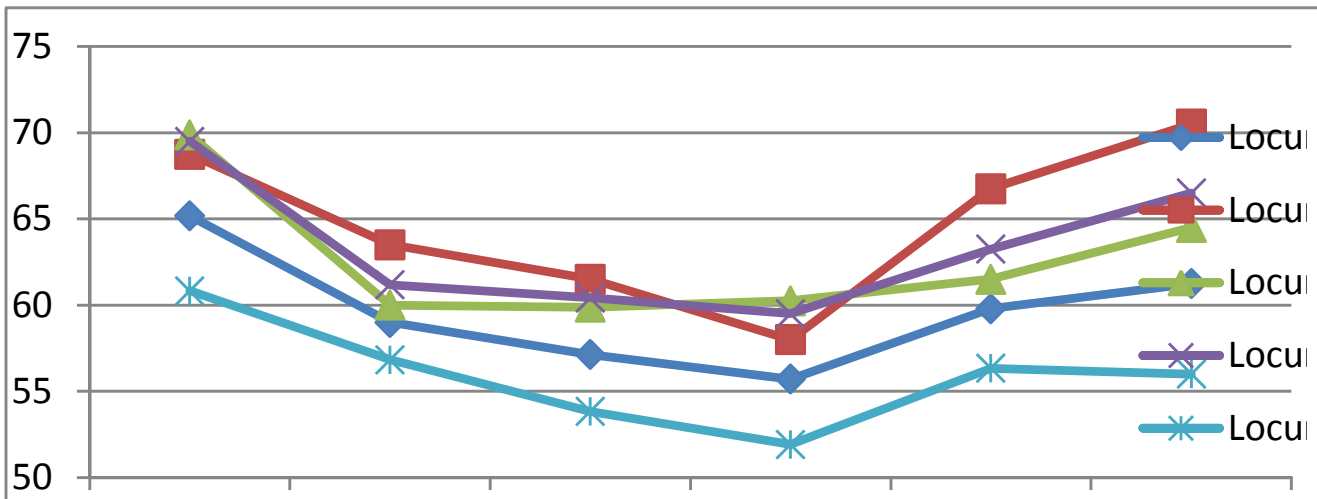

Figura 1. Eficiența aruncărilor pentru perioada 2005-2015

La aruncările din extreme cea mai bună eficiență medie au avut-o echipele clasate pe locurile 5-12 - 55,11\%, urmate de echipele clasate pe locurile 1-12 $54,58 \%$, iar apoi cele clasate pe locurile $1-4-53,54 \%$. Media tuturor echipelor a fost de 50,45\%, iar la ultimele 12 clasate a fost de 46,31\% (Fig. 2).

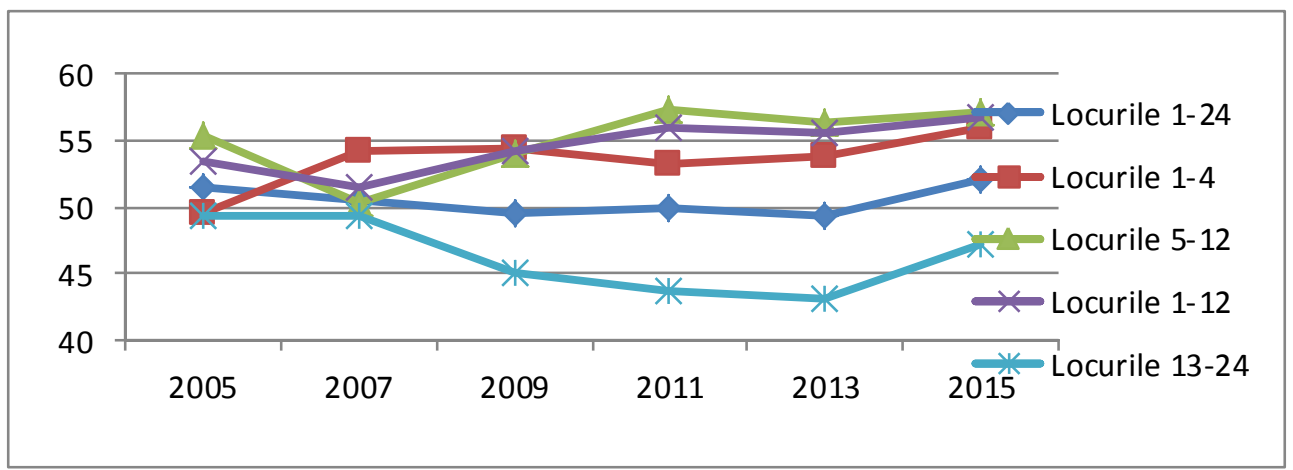

Figura 2. Eficiența aruncărilor din extreme pentru perioada 2005-2015 
În cazul aruncărilor de la 9m cea mai bună eficiență au avut-o echipele din prima jumătate a clasamentului (5-12 - 39,04\%, 1-12 - 39\%, 1-4 - 38,92\%), iar ultimele 12 clasate au avut o medie de 30,56\%; media tuturor echipelor a fost de 34,82\% (Fig. 3).

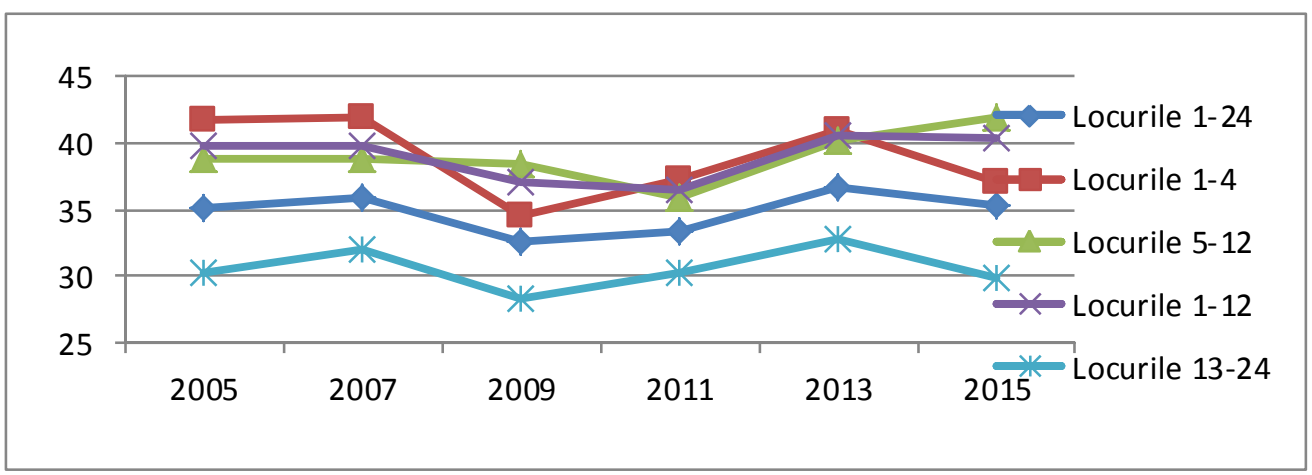

Figura 3. Eficiența aruncărilor de la 9m pentru perioada 2005-2015

La primele 12 echipe din clasament eficiența medie aruncărilor de la $7 \mathrm{~m}$ a fost în intervalul 75-77\%, iar pentru ultimele 12 clasate media a fost de 68,95\%. Media tuturor echipelor a fost de 72,54\% (Fig. 4).

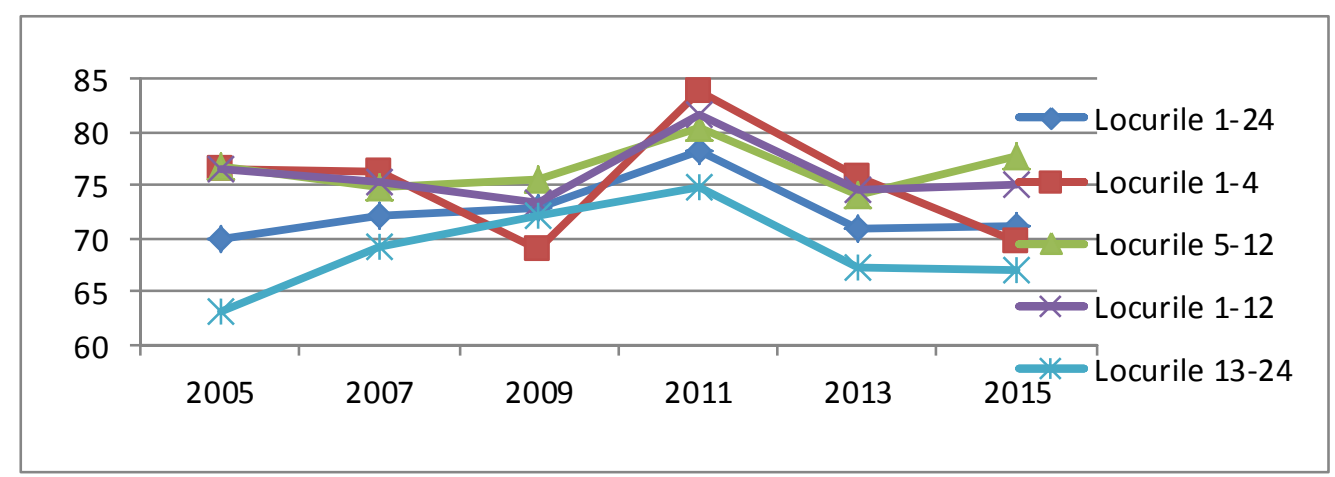

Figura 4. Eficiența aruncărilor de la 7m pentru perioada 2005-2015

Eficiența contraatacului a fost în limitele a $75-77 \%$ pentru primele 12 clasate, comparativ cu doar 71,03\% pentru ultimele 12 clasate; media pentru toate echipele a fost de 73,61\% (Fig. 5). 


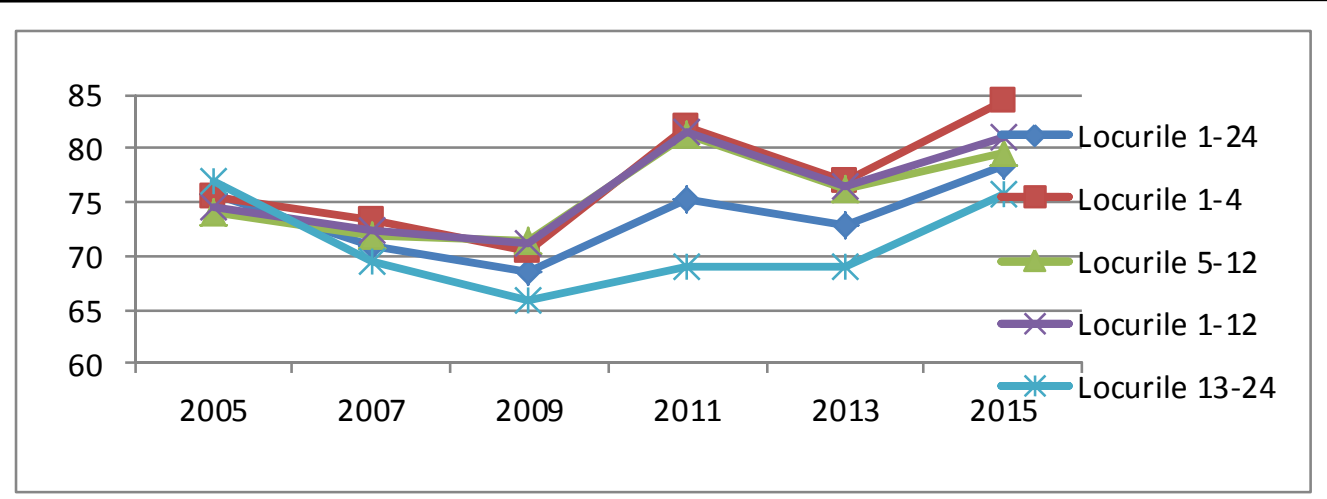

Figura 5. Eficiența contraatacului pentru perioada 2005-2015

Pentru toate echipele participante eficiența aruncărilor este în medie de 53,99\% (minim-51,21\%, maxim-59,36\%), pe când la primele 4 clasate media este de 58,63\% (minim-57\%, maxim-60,75\%). Pentru echipele clasate pe locurile 5-12 media este de 58,19\% (minim-55,38\%, maxim-64,13\%); situația pentru locurile 1-12 indică o medie de 58,33\% (minim-57,08\%, maxim-63\%), iar pentru locurile $13-24$ media este de 49,51\% (minim-47,50\%, maxim-55\%) (Fig. 6).

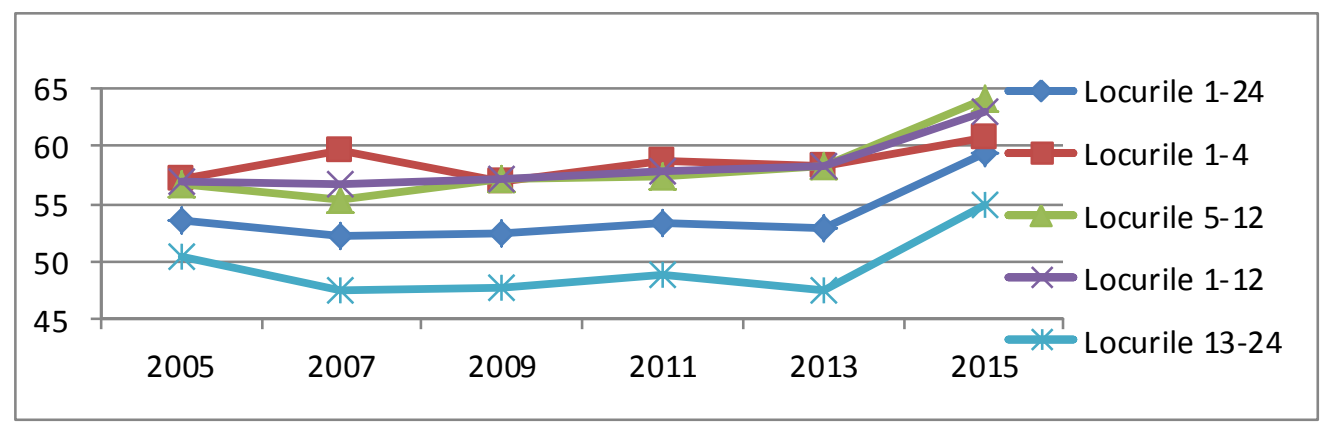

Figura 6. Eficiența aruncărilor pentru perioada 2005-2015

Eficiența portarilor este hotărâtoare în economia jocului, iar media eficienței lor în apărarea aruncărilor a fost de 31,91\% (minim-30,71\%, maxim$32,96 \%)$. În medie eficiența portarilor echipelor clasate pe locurile 1-4 este de $38,21 \%$ (minim-35,75\%, maxim-40\%); pentru următoarele 8 clasate media este de 34,29\% (minim-32,88\%, maxim-36,25\%), iar în cazul locurilor 1-12 media este de 35,6\% (minim-34,67\%, maxim-36,67\%). Pentru ultimele 12 clasate media eficienței este $28,21 \%$. Evoluția eficienței pentru cele 6 turnee finale analizate, pe categorii, este prezentată în figura 7, fiind vizibilă o tendință descendentă a eficienței portarilor. 


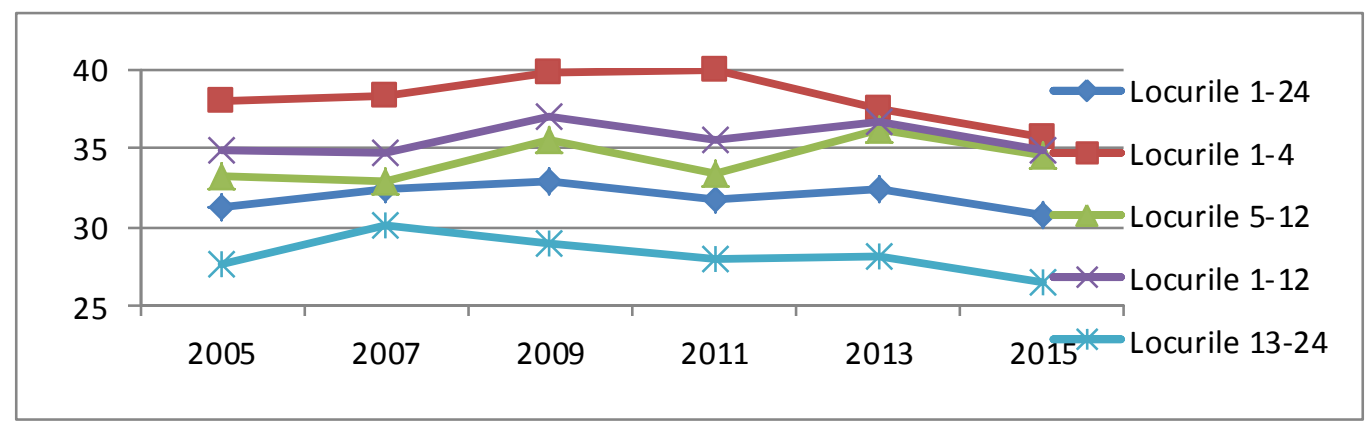

Figura 7. Eficiența portarilor pentru perioada 2005-2015

Numărul intercepțiilor realizate indică tendința ofensivă a echipei și posibilitatea de a înscrie goluri ușor pe contraatac. Media generală a echipelor participante este de 39,38 intercepții de echipă sau 5 intercepții pe joc. Pentru primele 4 clasate media este de 50,96 intercepții de echipă sau 5,65 intercepții pe joc; pentru locurile 1-12 media este de 45,49 intercepții de echipă sau 5,6 intercepții pe joc; la locurile 5-12 media este de 42,75 intercepții de echipă sau 5,3 intercepții pe joc; iar la ultimele 12 clasate media este de 33,26 intercepții de echipă sau 4,7 intercepții pe joc. Tendința descrescătoare în funcție de locul ocupat în clasamentul final este vizibilă în Fig. 8.

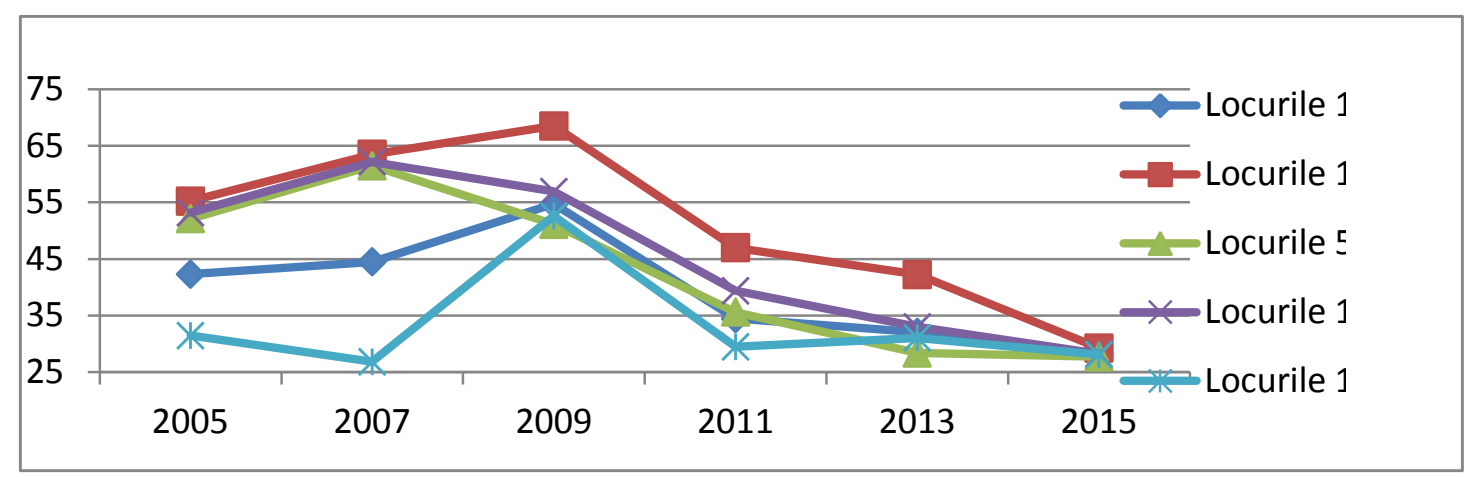

Figura 8. Numărul intercepțiilor pentru perioada 2005-2015

O altă acțiune care poate conduce la recuperarea mingii și creșterea eficienței apărării este blocarea aruncărilor, iar media pe echipă este de 23,22 aruncări blocate, respectiv 2,9 aruncări blocate pe joc. Pentru locurile 1-4 media este de 42,46 și 4,7 pe joc; la locurile 5-12 media este de 25,38 pe echipă și 3,17 pe joc; la primele 12 clasate media pe echipă este de 31,07 și 3,45 pe joc, iar la ultimele 12 clasate media este de 15,36 pe echipă și 2,2 pe joc (Fig. 9). 


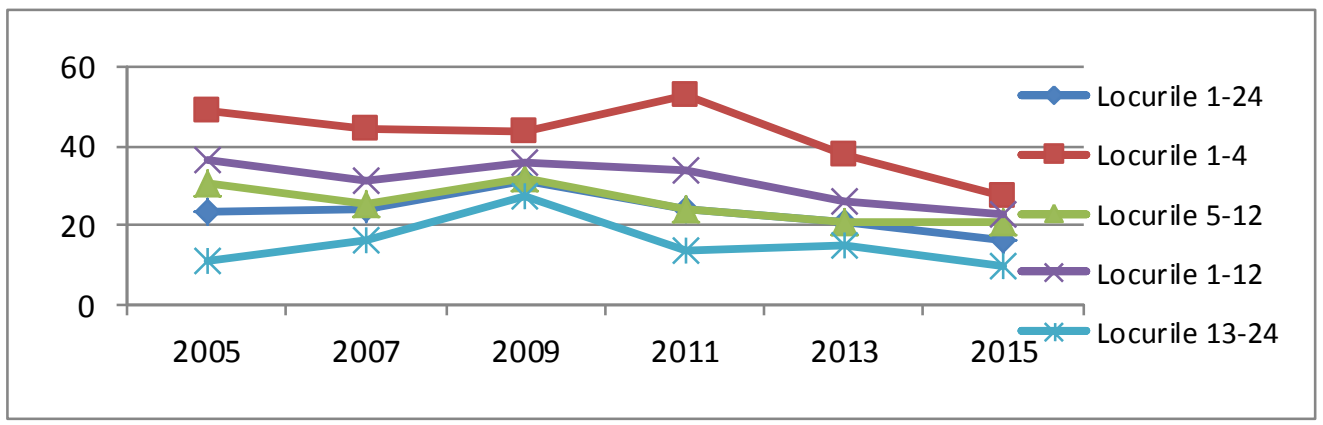

Figura 9. Evoluția aruncărilor blocate în perioada 2005-2015

Acest studiu a avut ca reper datele din literatura de specialitate (Taborsky, 2001), date care indică eficiența minimă a acțiunilor și la care am raportat datele obținute de noi (Tab. 6):

Tabel 6 Eficiența acțiunilor din studiul nostru comparativ cu cele din literatura de specialitate

\begin{tabular}{|l|c|c|c|c|}
\hline \multicolumn{1}{|c|}{$\begin{array}{c}\text { Eficiența } \\
\text { acțiunilor }\end{array}$} & $\begin{array}{c}\text { Eficiența } \\
\text { (Taborsky } \\
\text { F., 2001) }\end{array}$ & $\begin{array}{c}\text { Eficiența } \\
\text { pentru toate } \\
\text { echipele } \\
\text { participante } \\
\text { (studiul nostru) }\end{array}$ & $\begin{array}{c}\text { Eficiența } \\
\text { pentru } \\
\text { locurile 1-4 } \\
\text { (studiul } \\
\text { nostru) }\end{array}$ & $\begin{array}{c}\text { Eficiența } \\
\text { pentru } \\
\text { locurile 1-12 } \\
\text { (studiul } \\
\text { nostru) }\end{array}$ \\
\hline $\begin{array}{l}\text { Aruncările de la } \\
\text { 9m }\end{array}$ & $60 \%$ & $53,99 \%$ & $58,63 \%$ & $58,33 \%$ \\
\hline $\begin{array}{l}\text { Aruncări din } \\
\text { extreme }\end{array}$ & $40-45 \%$ & $34,82 \%$ & $38,92 \%$ & $39 \%$ \\
\hline $\begin{array}{l}\text { Aruncări de la } \\
\text { 6m }\end{array}$ & $55-60 \%$ & $50,45 \%$ & $53,54 \%$ & $54,58 \%$ \\
\hline $\begin{array}{l}\text { Aruncări pe } \\
\text { contraatac }\end{array}$ & $60-65 \%$ & $59,68 \%$ & $64,83 \%$ & $63,39 \%$ \\
\hline $\begin{array}{l}\text { Aruncări de la } \\
7 m\end{array}$ & $70-75 \%$ & $71,61 \%$ & $77,13 \%$ & $76,18 \%$ \\
\hline $\begin{array}{l}\text { Atacuri fără } \\
\text { aruncări }\end{array}$ & $75-80 \%$ & $72,54 \%$ & $75,21 \%$ & $76,13 \%$ \\
\hline Portari & $15-20 \%$ & $\begin{array}{c}39,38 / 5 \\
\text { intercepții }\end{array}$ & $\begin{array}{c}59,96 / 5,64 \\
\text { intercepții } \\
42,46 / 4,7 \\
\text { aruncări } \\
\text { blocate }\end{array}$ & $\begin{array}{c}45,49 / 5,6 \\
\text { intercepții } \\
\text { aruncări blocate } \\
\text { aruncări } \\
\text { blocate }\end{array}$ \\
\hline $\begin{array}{l}\text { Aruncările de la } \\
\text { 9m }\end{array}$ & $35-40 \%$ & $31,91 \%$ & $38,21 \%$ & $35,60 \%$ \\
\hline
\end{tabular}


Eficiența totală a aruncărilor este sub nivelul recomandat (53,99\%-58,63\% față de 60\%); în aceeași situație se află aruncările de la $9 \mathrm{~m}$ și din extreme, iar cele de la linia de $6 \mathrm{~m}$, pe contraatac și de la $7 \mathrm{~m}$ sunt în parametrii recomandați. În privința eficienței portarilor, aceasta este în limitele optime la primele 12 clasate, respectiv sub limită pentru toate cele 24 echipe.

\section{Concluzii}

Alte studii care tratează aceeași problemă indică faptul că există o anumită lipsă de constanță în timpul joculului și de la un joc la altul, fapt care face ca între primele 10 clasate să nu existe diferențe semnificative, iar greșelile pot fi decisive în privința eficienței și a locului ocupat în clasamentul final (Kovacs, 2014, p. 20; p. 26, 2016).

Este necesar ca evoluțiile să fie analizate în mod constant, după competițiile majore, pentru a indica tendințele evolutive ale jocului de handbal și pentru a stabili repere de eficiență obiective în pregătire și competiții (Leuciuc, Pricop, 2015a, pp. 42-48; 2015b, pp. 27-32; Leuciuc, Pricop, Grosu, Păcuraru, 2015, pp. 58-69).

Una din preocupările echipelor participante la campionatele mondiale pentru perioada analizată a fost creșterea eficienței aruncărilor (la toate categoriile analizate) care s-a manifestat printr-o tendință ascendentă deși ca medie la unele ediții au fost înregistrate scăderi (Fig. 1 - 6).

Tendința pozitivă a eficienței aruncărilor a influențat în mod negativ eficiența portarilor care a înregistrat o tendință descendentă deorece acești doi indicatori sunt într-o relație de inversă proporționalitate (Fig. 7).

Numărul mediu al intercepțiilor, respectiv al aruncărilor blocate este important pentru echipe deoarece favorizează creșterea eficienței apărării și înscrierea de goluri ușoare, iar echipele clasate în partea superioară a clasamentului și-au fãcut o strategie în acest sens, deși la ultimele 4 ediții s-a instalat o tendință descrescătoare (2016, 8 și 9).

Ca urmare a comparării datelor obținute în urma analizei efectuate ar trebui reconsiderate marjele de eficiență ale acțiunilor monitorizate pentru a fi repere utile în pregătire și competiție, impunându-se reconsiderarea modelului de joc în handbalul de performanță la nivel de seniori. Astfel pentru echipele care doresc o calificare este recomandabil ca eficiența acțiunilor să fie în marjele locurilor 1-12 din tab. 4 în contextul în care dispută jocuri cu echipe care se califică în mod constant la turneul final. În jocurile de calificare eficiența trebuie să fie mult mai mare deoarece echipele întâlnite sunt de o valoare mai slabă.

Echipele care aspiră la câștigarea competiției sau la medalii trebuie să depășească cerințele medii pentru locurile 1-4 (Tab. 2).

Ținând cont că studiul acoperă 6 ediții ale campionatelor mondiale datele obținute și analizate au grad înalt de veridicitate și pot fi utilizate care repere pentru următoarele competiții. 